DOI: $10.19195 / 0137-1134.114 .23$

\author{
MAŁGORZATA OFIARSKA \\ Uniwersytet Szczeciński \\ malgorzata.ofiarska@wpiaus.pl
}

\title{
KSZTAŁTOWANIE SIĘ KONCEPCJI ZWIĄZKU METROPOLITALNEGO W POLSCE PO 1990 ROKU
}

\begin{abstract}
Abstrakt: Od momentu restytucji samorządu terytorialnego w Polsce w 1990 roku jego ustrój podlega określonym procesom ewolucyjnym. Jednym z zasadniczych problemów analizowanych w ostatnich latach jest kwestia ustroju obszarów metropolitalnych, metropolii i aglomeracji (wcześniej dużych miast). Problem jest złożony, o czym świadczą między innymi podejmowane od ćwierćwiecza próby przyjęcia systemowych rozwiązań ustrojowych dla dużych miast i otaczających je gmin. Celem opracowania jest charakterystyka założeń lub projektów ustaw, przygotowywanych z różnych inicjatyw, ukierunkowanych na takie obszary. Prezentowane założenia i projekty były przygotowywane głównie w odpowiedzi na obserwowane doświadczenia funkcjonowania dobrowolnych form współpracy dużych miast i otaczających je gmin wskazujące, że rozwiązania polegające na wykorzystaniu instytucji związku komunalnego nie przynoszą w odniesieniu do dużych miast i obszarów metropolitalnych oczekiwanych rezultatów. Mimo powszechnego przekonania o konieczności przyjęcia rozwiązań ustawowych regulujących w Polsce status prawny obszarów metropolitalnych pierwsza ustawa o związkach metropolitalnych została uchwalona dopiero w 2015 roku, a na jej podstawie nie został utworzony żaden taki związek.
\end{abstract}

Słowa kluczowe: obszar metropolitalny, związek metropolitalny, powiat metropolitalny, zespół metropolitalny

\section{UWAGI WSTĘPNE}

Od restytucji samorządu terytorialnego w Polsce w 1990 roku jego ustrój podlega określonym procesom ewolucyjnym. Proces ten nie jest skończony, aczkolwiek powszechnie uznaje się, że najważniejsze problemy organizacyjne i funkcjonalne zostały już rozwiązane. Jednym z zasadniczych problemów analizowanych w ostatnich latach w doktrynie jest kwestia ustroju obszarów metropolitalnych, metropolii i aglomeracji (wcześniej dużych miast). Problem jest uniwersalny, interdyscyplinarny i złożony, o czym świadczą między innymi podejmowane od ćwierćwiecza próby przyjęcia systemowych rozwiązań ustrojowych dla dużych miast i otaczających je gmin (potrzebę sformułowania specjalnych rozwiązań dla obszarów miejskich wyrażano już w trakcie prac nad projektem ustawy o samo- 
rządzie terytorialnym). Celem opracowania jest wskazanie głównych kierunków założeń lub projektów ustaw, przygotowanych z różnych inicjatyw, dedykowanych takim obszarom. Prezentowane w opracowaniu założenia i projekty były przygotowywane głównie w odpowiedzi na obserwowane doświadczenia funkcjonowania dobrowolnych form współpracy wskazujące, że rozwiązania polegające na wykorzystaniu instytucji związku komunalnego nie przynoszą w odniesieniu do dużych miast i obszarów metropolitalnych oczekiwanych rezultatów. Poza zakresem rozważań pozostaną zasadniczo inicjatywy i projekty metropolitalne, w których poszukiwano odpowiedniej odrębnej koncepcji ustrojowej dla Warszawy. Problematyka ta została już wielokrotnie przedstawiona w piśmiennictwie ${ }^{1}$.

\section{GENEZA KONCEPCJI I ROZWIĄZAŃ PRAWNYCH UKIERUNKOWANYCH NA DUŻE MIASTA ORAZ AGLOMERACJE I METROPOLIE}

Wkrótce po restytuowaniu samorządu terytorialnego na poziomie gminy w 1990 roku dostrzeżono konsekwencje przyjęcia koncepcji gminy jednolitej (nieuwzględniającej różnic między poszczególnymi gminami, a wynikających zwłaszcza z ich charakteru miejskiego czy wiejskiego, wielkości i zdolności realizowania różnorodnych zadań publicznych) i jej negatywny wpływ na funkcjonowanie wielkich miast. W okresie tym prowadzono prace zmierzające do wprowadzenia kolejnej reformy administracji publicznej i poszukiwano nowych rozwiązań ustrojowych w odniesieniu do dużych miast w celu ich przygotowania do pełnienia w przyszłości funkcji miast zrównanych z powiatami. W projekcie ustawy o samorządzie powiatowym z 1993 roku proponowano przyjęcie rozwiązań określających istotę zespołów metropolitalnych oraz ustalających zasady ich tworzenia, organizacji, funkcjonowania i finansowania ${ }^{2}$. Zespół metropolitalny miały tworzyć jednostki samorządu terytorialnego (j.s.t.) na obszarze dużych aglomeracji miejskich: miasta nienależące do powiatów oraz gminy i powiaty bezpośrednio z nimi sąsiadujące lub powiązane funkcjonalnie. Zespół taki miał mieć osobowość prawną i wykonywać zadania publiczne w imieniu własnym i na własną odpowiedzialność. Do zakresu działania zespołu metropolitalnego chciano przekazać: planowanie strategii rozwoju i zagospodarowania obszaru zespołu metropolital-

1 Inicjatywy te prezentują między innymi B. Jaworska-Dębska, Poszukiwanie dróg optymalizacji ustroju dużych miast, „Samorząd Terytorialny” 1992, nr 12, s. 30-31; S. Faliński, Warszawski samorzą terytorialny w latach 1990-2002. Geneza, ustrój, idee ustrojowe, aktywność, Warszawa 2013, s. 89-94; H. Gronkiewicz-Waltz, B. Jakacka, Ewolucja samorzadu warszawskiego, [w:] Misja publiczna, wspólnota, państwo: studia z prawa i administracji. Księga dedykowana pamięci profesora Michała Kuleszy, t. 1, Wrocław 2016, s. 31 n.

2 Projekt ustawy o samorządzie powiatowym z dnia 10 sierpnia 1993 r. zob. Dyskusja o powiatach, t. 2. Projektowanie ustawodawstwa powiatowego, cz. 1, red. R. Sowiński, Poznań 1994. 
nego, wspomaganie przedsięwzięć publicznych o znaczeniu metropolitalnym oraz wspomaganie j.s.t. wchodzących w skład zespołu, w celu łagodzenia rażących nierówności w sferze zaspokajania potrzeb wspólnot samorządowych. W celu wykonywania zadań publicznych o znaczeniu metropolitalnym zespoły mogłyby między innymi tworzyć związki komunalne i zawierać porozumienia komunalne. Utworzenie zespołu metropolitalnego następowałoby ustawą. Ustalono katalog obligatoryjnych źródeł dochodów zespołu metropolitalnego, obejmujący składki j.s.t., udziały w nadwyżkach budżetowych oraz subwencję ogólną przekazywaną z budżetu państwa. Propozycję określenia statusu prawnego zespołów metropolitalnych dostrzeżono w doktrynie. Uznano ją za dyskusyjną i prowadzącą do tworzenia nie tylko odrębnego, lecz także ponadpowiatowego stopnia samorządu terytorialnego ${ }^{3}$.

W tym samym okresie podejmowano inne próby wypracowania przyszłych rozwiązań ustrojowych dla obszarów dużych miast, ale miały one charakter tymczasowy, nietrwały i eksperymentalny, stanowiąc de facto prototyp przyszłego powiatu. Takie cele przyświecały uruchomionemu w 1993 roku tak zwanemu programowi pilotażowemu reformy administracji publicznej (przeznaczonemu dla dużych miast) ${ }^{4}$, którego merytoryczną kontynuację stanowiły miejskie strefy usług publicznych $^{5}$ funkcjonujące do 1 stycznia 1999 roku (przeznaczone dla mniejszych miast i otaczających je gmin).

\section{ZAŁOŻENIA WYBRANYCH KONCEPCJI I PROJEKTÓW ROZWIĄZAŃ PRAWNYCH DOTYCZĄCYCH OBSZARÓW METROPOLITALNYCH}

W kolejnych latach poddano dyskusji i ocenie kilka koncepcji dotyczących pozycji prawnej, zadań, organizacji oraz zasad funkcjonowania i finansowania dużych miast, aglomeracji i metropolii, mających charakter uniwersalny lub indywidualny (jednostkowy, przeznaczony dla konkretnej aglomeracji/metropolii) ${ }^{6}$, opracowanych zarówno przez przedstawicieli doktryny, jak i zespoły powołane

3 Tak L. Kieres, Uwagi o projekcie z dnia 29 lipca 1993 r. ustawy o samorzadzie powiatowym, [w:] Dyskusja o powiatach, s. 79. Także K. Podgórski zgłaszał uwagi odnośnie do proponowanych rozwiązań dotyczących zespołu metropolitalnego: idem, Uwagi i propozycje szczegółowe do projektu ustawy o samorzadzie powiatowym (z dnia 10 sierpnia 1993 r.), [w:] Dyskusja o powiatach, s. 90.

${ }^{4}$ M. Kulesza, Miejski program pilotażowy reformy administracji publicznej (ogólne omówienie), „Samorząd Terytorialny” 1995, nr 12, s. 71. Zob. także idem, Budowanie samorząu. Wybór tekstów ze „Wspólnoty” 1990-2007, Warszawa 2008, s. 113.

5 A. Władyka, M. Wójcik, M. Zawicki, Powstawanie miejskich stref usług publicznych, [w:] Od miejskiej strefy ustug publicznych do powiatu, red. J. Hausner, S. Mazur, Kraków 1998, s. 31.

6 Takiej klasyfikacji dokonują B. Jaworska-Dębska, O istocie związków metropolitalnych, [w:] O prawie administracyjnym $i$ administracji. Refleksje. Księga jubileuszowa dedykowana Profesor Małgorzacie Stahl, red. B. Jaworska-Dębska, Łódź 2017, s. 230; oraz R. Gawłowski, Metropolie 
przez organy administracji rządowej (ministra spraw wewnętrznych i administracji, wojewodę śląskiego) czy zespoły parlamentarne.

M. Kulesza współtworzył, przygotował i kierował wdrożeniem kilku projektów i programów przeznaczonych dla dużych miast (między innymi miejskiego programu pilotażowego, miejskiej strefy usług publicznych, ustawy o ustroju m.st. Warszawy z 1994 roku). Rządowy projekt ustawy o Zespole Gmin Warszawskich i o ustroju miasta stołecznego Warszawy z $1994 \mathrm{roku}^{7}$ zakładał utworzenie związku komunalnego Warszawy pod nazwą ,Zespół Gmin Warszawskich” przez gminy warszawskie położone na obszarze dotychczasowego związku dzielnic-gmin Warszawy. Szczegółowe rozwiązania dotyczące zakresu działania zespołu, organizacji oraz zasad funkcjonowania i finansowania wzorowano na propozycji sformułowanej w projekcie powiatowym dla zespołów metropolitalnych ${ }^{8}$. Propozycji utworzenia Zespołu Gmin Warszawskich nie uwzględniono jednak w ustawie z 5 marca 1994 roku o ustroju miasta stołecznego Warszawy 9 . W późniejszym okresie M. Kulesza, proponując optymalny model zarządzania aglomeracjami miejskimi, wskazywał jako właściwe podejście funkcjonalne zakładające wyodrębnienie dwóch płaszczyzn zarządzania i grup zadań publicznych (programowania rozwoju całej aglomeracji oraz innych wspólnych zadań z różnych dziedzin, jak na przykład komunikacja zbiorowa czy wodociągi), które powinny być realizowane przez „władzę metropolitalną”. Jednocześnie krytycznie oceniał podejście strukturalne zakładające zmiany w podziale terytorialnym (zarówno przez włączanie do dużego miasta kolejnych jednostek lub ich części, jak i utworzenie specjalnej jednostki podziału terytorialnego wyższego stopnia — ,województwa aglomeracyjnego", ,powiatu metropolitalnego"). Postulował przyjęcie tak zwanych ustaw metropolitalnych dla trzech największych zespołów miejskich (śląskiego, stołecznego i nadmorskiego) oraz ustawy o pozostałych dużych miastach, w których byłyby ustalone podstawowe zasady programowania rozwoju w skali całej aglomeracji ${ }^{10}$.

Charakter uniwersalny miała koncepcja powiatu metropolitalnego zaproponowana w 2005 roku przez H. Izdebskiego w kompleksowym projekcie ustawy o zmianie ustawy o wprowadzeniu zasadniczego trójstopniowego podziału terytorialnego państwa oraz o zmianie niektórych innych ustaw dotyczących samorządu terytorialnego, przygotowanym w latach 2004-2005 na potrzeby projektu Narodowego Planu Rozwoju na lata 2007-2013. Istotnym elementem projektu było wpro-

jako szczególne jednostki samorządu terytorialnego, [w:] R. Gawłowski, P. Machalski, K. Makowski, Samorząd terytorialny w systemie administracji publicznej, Warszawa 2017, s. 184.

7 Druk Sejmu II kadencji nr 248.

8 Tak M. Kulesza, Budowanie samorzadu, s. 138 n.

9 Tekst pierwotny Dz.U. Nr 48, poz. 195. Rozpatrywano wspólnie cztery projekty.

10 M. Kulesza, Budowanie samorzadu, s. 359-360; idem, Kilka uwag o zarzadzaniu aglomeracja miejska. Wyzwania instytucjonalne i prawne, „Samorząd Terytorialny” 2010, nr 6, s. 69. Zob. także B. Jaworska-Dębska, O istocie związków metropolitalnych, s. 232. 
wadzenie dwunastu powiatów metropolitalnych, w tym szczególnego powiatu stolicy o statusie regionalnym ${ }^{11}$, realizujących oprócz zadań typowych dla powiatu także zadania charakterystyczne dla powiatu metropolitalnego (między innymi z zakresu planowania i zagospodarowania przestrzennego; zarządu drogami publicznymi, oprócz dróg ekspresowych i autostrad; ustalenia sieci szkół ponadgimnazjalnych i specjalnych). Powiat metropolitalny miał mieć dwa organy — stanowiący i kontrolny (radę) oraz wykonawczy (marszałka powiatu metropolitalnego, wybieranego w wyborach bezpośrednich). Projekt ten nie był przedmiotem prac parlamentarnych. Do koncepcji powiatu metropolitalnego autor ten nawiązał także w późniejszym okresie, dokonując identyfikacji zadań metropolitalnych (głównie w kwestii bezpieczeństwa i porządku publicznego, zarządzania kryzysowego, planowania i zagospodarowania przestrzennego, zarządu dróg powiatowych, wojewódzkich i krajowych oraz koordynowania transportu zbiorowego) i poszukując właściwej formy ich realizacji. Uznał, że w ramach obowiązujących standardów konstytucyjnych i międzynarodowych jedyną możliwością było przyjęcie rozwiązania polegającego na stworzeniu z obszarów metropolitalnych szczególnych jednostek zasadniczego podziału terytorialnego - j.s.t. w postaci powiatów metropolitalnych będących szczególną kategorią powiatu. Powiat metropolitalny realizowałby tylko zadania metropolitalne i posiadałby strukturę organizacyjną, co do zasady wzorowaną na powiecie (z zastrzeżeniem konieczności rozbudowy o organ reprezentujący j.s.t. oraz podstawowych partnerów społeczno-gospodarczych i ze sfery nauki) ${ }^{12}$.

Zespół kierowany przez E. Knosalę przedstawił koncepcję specjalnej ustawy dla konurbacji śląskiej, której istotą miało być utworzenie związku regionalnego (o nazwie Śląsk lub Silesia) o statusie ustrojowym jednostki samorządu regionalnego. Z mocy prawa członkami związku stałyby się wymienione w ustawie miasta na prawach powiatu. Związek realizowałby zadania własne (obowiązkowe i dobrowolne, wskazane przez organ stanowiący związku), zlecone oraz przekazane jemu w drodze porozumienia przez członków związku. Katalog zadań obowiązkowych związku obejmowałby między innymi zadania z zakresu planowania przestrzennego i rozwojowego, transportu zbiorowego, komunikacji regionalnej, ochrony zabytków kultury przemysłowej i zaopatrzenia w wodę. Związek regionalny, będący korporacją prawa publicznego, miałby dwa organy — stanowiący (pochodzący

11 H. Izdebski, Samorząd terytorialny. Podstawy ustroju i działalności, Warszawa 2014, s. 276, 378. Por. także Propozycje zmian legislacyjnych wynikające z Narodowego Programu Rozwoju na lata 2007-2013, Warszawa październik 2005.

12 H. Izdebski, Zadania metropolitalne i instytucjonalne sposoby ich realizacji, „Samorząd Terytorialny" 2010, nr 6, s. 62 i 67-68. Omawiany projekt ustawy stał się inspiracją innych koncepcji funkcjonowania obszarów metropolitalnych. Zob. I. Zachariasz, Koncepcja utworzenia powiatów metropolitalnych, [w:] Sprawne państwo. Propozycje zmian w funkcjonowaniu jednostek samorządu terytorialnego w Polsce, red. P. Kopyciński, Kraków 2015, s. 54-68; P. Kopyciński, W kierunku trzeciej reformy samorządu terytorialnego, „Samorząd Terytorialny” 2016, nr 7-8, s. 176. 
z wyborów powszechnych i bezpośrednich) i wykonawczy (wybierany przez organ stanowiący). Bieżącą działalnością związku kierowałby dyrektor regionalny (wybierany w konkursie). W okresie przejściowym działalność związku byłaby finansowana z dotacji budżetowej. Docelowo działalność finansowa związku miała być prowadzona na zasadach określonych w ustawie o finansach publicznych i o samorządzie województwa. Rozważano także możliwość wprowadzenia instytucji wpłat wnoszonych przez członków związku, o charakterze wyrównawczym, w wysokości uzależnionej od potencjału gospodarczego poszczególnych członków oraz zakresu korzystania z instytucji regionalnych sfinansowanych ze środków związku $^{13}$.

Projekt ustawy metropolitalnej prezentowany w latach 2007-2008 przez C. Martysza i Z. Klatkę, przygotowany na zlecenie wojewody śląskiego, nawiązywał między innymi do doświadczeń niemieckich w zakresie zarządzania aglomeracjami i do koncepcji związku komunalnego uregulowanej w ustawie o samorządzie gminnym. Zakładał utworzenie obligatoryjnego związku komunalnego, do którego mogłyby przystępować gminy sąsiadujące, ale po akceptacji ministra właściwego do spraw administracji ${ }^{14}$.

Projekty przygotowane przez zespoły kierowane przez C. Martysza i przez E. Knosalę nie były przedmiotem prac parlamentarnych. Miały natomiast, łącznie z koncepcją opracowaną przez M. Kuleszę, stanowić podstawę opracowania — na zlecenie rządu - uniwersalnej ustawy regulującej funkcjonowanie związków metropolitalnych. Planowano przyjęcie katalogu podstawowych obligatoryjnych zadań takich związków (obejmujących między innymi zadania z zakresu planowania strategicznego dla danego obszaru, transportu publicznego, komunikacji i ochrony środowiska) oraz źródeł ich finansowania (pochodzących zarówno bezpośrednio $\mathrm{z}$ budżetu państwa, na przykład w formie udziału w określonych podatkach, jak też z dobrowolnych składek gmin członkowskich oraz środków samodzielnie pozyskiwanych przez związki). Związki miały realizować także zadania fakultatywne, uwzględniające specyfikę danego obszaru metropolitalnego. W pierwszym etapie wdrożenia ustawy funkcjonowałyby jedynie - mające charakter pilotażowy - dwa związki (na Śląsku i w Trójmieście). Docelowo planowano utworzenie związku dla kilku obszarów metropolitalnych (górnośląskiego, krakowskiego, łódzkiego, pomorskiego, poznańskiego, warszawskiego i wrocławskiego) ${ }^{15}$.

13 Więcej E. Knosala, R. Stasikowski, Prawne i organizacyjne problemy funkcjonowania aglomeracji ze szczególnym uwzględnieniem aglomeracji ślaskiej, [w:] Problemy współczesnego ustrojoznawstwa. Księga Jubileuszowa Procesora Bronisława Jastrzębskiego, Olsztyn 2007, s. 279-285; E. Knosala, A. Gołuch, R. Stasikowski, Uwagi w sprawie koncepcji ustrojowej aglomeracji ślaskiej wraz z projektem ustawy o Regionalnym Związu Komunalnym ,,Silesia”, „Samorząd Terytorialny” 2007, nr 12, s. 45-54.

14 B. Jaworska-Dębska, O istocie związków metropolitalnych, s. 230.

15 Polska Agencja Prasowa, 15 lutego 2008 r.; https://www.wprost.pl/kraj/123753/metropolie-od-2010-r.html (dostęp: 15.12.2017). 
W styczniu 2007 roku Minister Spraw Wewnętrznych i Administracji powołał Zespół do Spraw Uregulowania Funkcjonowania Obszarów Metropolitalnych w celu przygotowania podstawowych założeń regulacji prawnej obszarów metropolitalnych. W ramach jego prac, zmierzających do wypracowania optymalnych rozwiązań prawnych dotyczących funkcjonowania obszarów metropolitalnych, przygotowano diagnozę problemów rozwoju obszarów metropolitalnych i rekomendację delimitacji obszarów metropolitalnych w Polsce. W październiku 2007 roku Rada Ministrów przyjęła założenia do projektu ustawy metropolitalnej (zakładającej uwzględnienie w koncepcji przyszłej formy organizacyjnej obszaru metropolitalnego obligatoryjnego ustawowego związku metropolitalnego), oparte na wynikach prac tego zespołu ${ }^{16}$. Rezultatem prac zespołu było przygotowanie projektu ustawy o rozwoju miast i obszarach metropolitalnych ${ }^{17}$, zaprezentowanego na posiedzeniu Komisji Wspólnej Rządu i Samorządu Terytorialnego w maju 2008 roku i jego wykorzystanie w projekcie ustawy z 2008 roku o rozwoju miast, centrach rozwoju regionalnego i obszarach metropolitalnych. Uznano, że w celu rozwiązywania problemów zarządzania publicznego, wspólnych dla j.s.t. na terenie dużych aglomeracji miejskich powinny być tworzone — przez Radę Ministrów na zasadach określonych w ustawie - zespoły metropolitalne. Przynależność do zespołu gmin i powiatów w całości znajdujących się na obszarze metropolitalnym miała być obligatoryjna. Zespół metropolitalny miał mieć osobowość prawną i wykonywać zadania publiczne w imieniu własnym i na własną odpowiedzialność. Do zakresu działania tego zespołu planowano przekazać między innymi sprawy: programowania strategii rozwoju i zagospodarowania obszaru metropolitalnego; przedsięwzięć, zwłaszcza o charakterze infrastrukturalnym, mających znaczenie dla obszaru metropolitalnego jako całości i promocji obszaru. Ponadto do zespołu należeć miała koordynacja działalności jednostek samorządu lokalnego na obszarze metropolitalnym w określonych sprawach (między innymi: ładu przestrzennego i ochrony środowiska, komunikacji i transportu zbiorowego, bezpieczeństwa zbiorowego i porządku publicznego, zarządzania w warunkach kryzysowych). Zespół mógłby także realizować inne zadania publiczne. W celu realizacji tych zadań organy zespołu mogłyby powoływać jednostki organizacyjne i prowadzić działalność na zasadach określonych w ustawie o gospodarce komunalnej. Zespół metropolitalny miałby dwa kolegialne organy - stanowiący i kontrolny (zgromadzenie, składające się z delegatów wszystkich jednostek samorządu lokalnego należących do zespołu) oraz wykonawczy (kolegium wykonawcze zespołu, liczące co najmniej trzech członków, w którego skład wejść mieli prezydenci miast na prawach powiatu i przedstawiciele wszystkich powiatów należących do zespołu,

16 http://mswia.gov.pl/pl/aktualnosci/5052,Zalozenia-do-projektu-Ustawy-Metropolitalnej. html (dostęp: 16.12.2017). Wnioski końcowe z prac Zespołu do Spraw Uregulowania Funkcjonowania Obszarów Metropolitalnych zob. www.regioportal.pl/vdata/_pliki/dzialalnos.../regio[4]_wnioski_metropolie.doc (dostęp: 15.12.2017).

17 Projekt zob. https://www.mswia.gov.pl/download/1/4530/1-4530.pdf (dostęp: 15.12.2017). 
chyba że statut zespołu stanowiłby inaczej). Podstawą gospodarki finansowej miał być budżet zespołu. Ustalono katalog obligatoryjnych źródeł dochodów zespołu (obejmujący między innymi składki j.s.t. oraz udział w podatku od towarów i usług, a w projekcie ustawy o rozwoju miast, centrach rozwoju regionalnego i obszarach metropolitalnych także udział w podatku dochodowym od osób prawnych) oraz fakultatywnych źródeł dochodów (mogły nimi być między innymi dotacje i subwencje z budżetu państwa, fundusze celowe, środki pochodzące z programów Unii Europejskiej). W obu projektach wskazano dwanaście obszarów metropolitalnych: m.st. Warszawa, czternaście miast na prawach powiatu wspólnie tworzących metropolię górnośląską, Łódź, Kraków, trzy miasta na prawach powiatu wspólnie tworzące metropolię gdańską, Wrocław, Poznań, Bydgoszcz i Toruń, Szczecin, Lublin, Białystok, Rzeszów. Propozycje określenia statusu prawnego zespołów metropolitalnych zostały dostrzeżone w doktrynie (między innymi uznano je za powtórzenie propozycji już wcześniej formułowanych ${ }^{18}$ i przypisano im znaczenie porządkujące $\left.{ }^{19}\right)$. Nie zostały one rekomendowane przez Radę Legislacyjną $\mathrm{w}$ przedstawionej do zaopiniowania wersji do dalszych prac legislacyjnych ${ }^{20}$.

Kolejną próbę wypracowania przyszłych rozwiązań ustrojowych dla obszarów metropolitalnych podjęto w projekcie ustawy o polityce miejskiej i współpracy jednostek samorządu terytorialnego w tym zakresie oraz o zmianie niektórych innych ustaw z 15 września 2008 roku. Proponowano dualny sposób tworzenia obszaru metropolitalnego. Ustawą utworzone zostałyby dwa obszary metropolitalne - warszawski i górnośląski. Kolejne obszary mogłaby utworzyć Rada Ministrów na zasadach określonych w ustawie (z łączną liczbą mieszkańców nie mniejszą niż 500 tys., przy gęstości zaludnienia na tym obszarze nie mniejszej niż 200 mieszkańców na $1 \mathrm{~km}^{2}$ ). W celu prowadzenia spraw obszaru metropolitalnego proponowano utworzenie zespołu metropolitalnego, do którego z mocy prawa należałyby gminy i powiaty położone w całości na tym obszarze. Zespół metropolitalny miał mieć osobowość prawną i wykonywać zadania publiczne w imieniu własnym i na własną odpowiedzialność. Do zakresu działania zespołu planowano przekazać analogiczne sprawy jak proponowane we wcześniejszych projektach z 2008 roku. Podobnie jak we wcześniejszych projektach zespół metropolitalny miałby dwa kolegialne organy - stanowiący i kontrolny (zgromadzenie, składające się z delegatów wszystkich jednostek samorządu lokalnego należących do zespołu) oraz wykonawczy (zarząd zespołu liczący co najmniej trzech członków, którego skład ustalany byłby według zasad określonych w ustawie). W zakresie właściwości

18 B. Dolnicki, Ustrój metropolii — współczesne koncepcje, „Administracja Publiczna. Studia Krajowe i Międzynarodowe" 2010, nr 2, s. 199-204.

19 B. Edwarczyk, Rozwój obszarów metropolitalnych w świetle transformacji samorzadu terytorialnego w Polsce w latach 1990-2014, RPEiS 2015, z. 3, s. 309.

20 Opinia Rady Legislacyjnej z 14 sierpnia 2008 r. o projekcie ustawy o rozwoju miast, centrach rozwoju regionalnego i obszarach metropolitalnych (RL-0303-53/08), „Przegląd Legislacyjny” 2009, nr 1-2, s. 201-204. 
zgromadzenia i zadań zarządu w projekcie zaproponowano rozwiązania analogiczne jak przyjęte w ustawach samorządowych dla organów j.s.t. Podstawą gospodarki finansowej miał być budżet zespołu. Ustalono katalog źródeł dochodów zespołu obligatoryjnych (obejmujący składki j.s.t., dochody z majątku zespołu i odsetki od środków finansowych gromadzonych na jego rachunkach bankowych) oraz fakultatywnych (mogły nimi być między innymi wpłaty j.s.t. przeznaczone na realizację przedsięwzięć infrastrukturalnych, dotacje z budżetu państwa lub funduszy celowych, środki pochodzące z programów Unii Europejskiej). Oceny tego projektu były zróżnicowane. $Z$ jednej strony zgłaszano zastrzeżenia co do zakresu jego zastosowania czy wręcz zasadności i zgodności z konstytucją oraz krytycznie oceniano propozycję niektórych rozwiązań (między innymi niewydajnych źródeł dochodów czy wprowadzenie zasady głosowania uchwał zgromadzenia podwójną bezwzględną większością). Z drugiej strony natomiast pozytywnie oceniano stworzenie insty tucjonalnej płaszczyzny współpracy j.s.t. i szansy na zdynamizowanie ich rozwoju ${ }^{21}$.

Wcześniej omówioną propozycję legislacyjną wykorzystywał natomiast rządowy projekt ustawy o polityce miejskiej państwa i współpracy jednostek samorządu w tym zakresie z 8 maja 2009 roku. W odróżnieniu jednak od projektu z 15 września 2008 roku formułował propozycję tworzenia obszarów metropolitalnych jedynie przez Radę Ministrów (z łączną liczbą mieszkańców nie mniejszą niż 2 mln, przy gęstości zaludnienia przekraczającej 200 mieszkańców na 1 km²). Podobnie w celu prowadzenia spraw obszaru metropolitalnego proponowano utworzenie zespołu metropolitalnego, do którego przynależność z mocy prawa uzyskiwałyby gminy i powiaty położone w całości na tym obszarze. Analogicznie określono zakres działania zespołu metropolitalnego i zaproponowano podobne zasady organizacji zespołu metropolitalnego (z tym że przewodniczącym zarządu miał być według projektu z 2008 roku prezydent największego miasta zespołu, natomiast według projektu z 2009 roku prezydent największego pod względem liczby mieszkańców miasta zespołu lub marszałek województwa). W zakresie właściwości zgromadzenia i zadań zarządu zaproponowano rozwiązania analogiczne jak przyjęte w ustawach samorządowych dla organów j.s.t. Podstawą gospodarki finansowej miał być budżet zespołu. Ustalono również tożsamy katalog obligatoryjnych i fakultatywnych źródeł dochodów zespołu jak we wcześniejszym projekcie. W obu projektach zdefiniowano obszar metropolitalny jako ciągły przestrzennie układ osadniczy obejmujący co najmniej jedno miasto na prawach powiatu wraz z otaczającymi je gminami. Obszar taki powinien charakteryzować się mocnymi związkami funkcjonalno-przestrzennymi, w tym dużym przepływem osób, towarów i usług, oraz intensywnym zagospodarowaniem i dużą gęstością

21 Zob. A. Ignasiak-Szulc, Dylematy ,, dekretowania” zasad wspierania procesu metropolizacji w Polsce, [w:] Wielkie miasta, aglomeracje, metropolie, red. S. Flejterski, „Ekonomiczne Problemy Usług" 30, Szczecin 2009, s. 65-66 oraz cytowana tam literatura. 
zaludnienia w skali całego terenu. Prace legislacyjne nad analizowanym projektem, ze względu na rozbieżności między stroną samorządową a rządową w trakcie przeprowadzanych konsultacji, wstrzymano w 2010 roku $^{22}$.

Z powodu wstrzymania prac nad przygotowaniem rozwiązań adresowanych do wszystkich obszarów metropolitalnych podjęto prace w celu przygotowania projektu ustawy metropolitalnej jedynie dla określonego obszaru. W latach 2011-2012 pracowano nad przyjęciem podstaw prawnych obligatoryjnego współdziałania dla czternastu miast na prawach powiatu (tworzących Górnośląski Związek Metropolitalny) z siedzibą władz powiatu metropolitalnego w Katowicach. Struktura i zakres kompetencji organów powiatu metropolitalnego miały nawiązywać do rozwiązań przyjętych w ustawie o samorządzie powiatowym. Powiatowi metropolitalnemu zamierzano przekazać wykonywanie określonych zadań publicznych o charakterze strategicznym, zwłaszcza z zakresu zagospodarowania przestrzennego, publicznego transportu zbiorowego i dróg powiatowych; ochrony środowiska, gospodarki wodno-ściekowej, gospodarki odpadami; uchwalania programów dotyczących bezpieczeństwa publicznego i zrządzania kryzysowego ${ }^{23}$. W tym okresie projektem indywidualnym, przeznaczonym dla aglomeracji górnośląskiej był projekt zaprezentowany w 2012 roku przez zespół w składzie: B. Dolnicki, J. Glumińska-Pawlic i C. Martysz. Jego istotą było zachowanie istniejącego zasadniczego trójstopniowego podziału terytorialnego państwa i utworzenie kolejnej kategorii powiatu - powiatu metropolitalnego, w którego skład wchodziłyby ustawowo wskazane miasta na prawach powiatu. Powiat metropolitalny przejmowałby część zadań miast, których efektywne wykonywanie, ze względu na ponadlokalny charakter, przekraczało możliwości poszczególnych miast i związków komunalnych, między innymi z zakresu wspólnej strategii rozwoju oraz studium uwarunkowań i kierunków zagospodarowania przestrzennego; publicznego transportu zbiorowego; zarządzania drogami publicznymi krajowymi i wojewódzkimi; ochrony środowiska, gospodarki wodno-ściekowej i gospodarki odpadami; bezpieczeństwa publicznego i zarządzania kryzysowego; promocji powiatu metropolitalnego. Stojąc na stanowisku, że w jak najmniejszym stopniu należy ingerować w istniejące rozwiązania ustrojowe, autorzy projektu proponowali w szerokim zakresie przyjęcie rozwiązań analogicznych do przyjętych w ustawie o samorządzie powiatowym. Powiat metropolitalny miał mieć dwa organy - stanowiący i kontrolny (dziewięcioosobową radę pochodzącą z wyborów bezpośrednich, której przewodniczyłby starosta) i wykonawczy (wybierany przez radę trzyosobowy zarząd, w składzie starosta jako przewodniczący oraz dwóch wicestarostów). W chwili złożenia projektu w Sejmie powiat metropolitalny obejmowałby centralne miasta aglomeracji górnośląskiej. Intencją autorów było jednak stworzenie uniwersalnych ram prawnych

22 M. Ofiarska, Koncepcje i kierunki ewolucji form współdziałania gmin we Francji - wnioski dla Polski, [w:] Finanse publiczne i prawo finansowe. Realia i perspektywy zmian. Ksiega Jubileuszowa dedykowana Profesorowi Eugeniuszowi Ruśkowskiemu, Białystok 2012, s. 271.

23 Ibidem, s. 272. 
pozwalających na ich zastosowanie do ustroju innych obszarów metropolitalnych, do ich struktury i lokalnej specyfiki ${ }^{24}$. Zaprezentowana propozycja skierowana do jednego obszaru metropolitalnego nie zyskała akceptacji rządu, w zamian przeprowadzono konsultacje na temat najważniejszych dylematów dotyczących preferencji przyjmowania szczegółowych rozwiązań w zakresie wyznaczania obszarów metropolitalnych, realizowanych tam zadań, a także struktury organizacyjnej oraz zasad zarządzania obszarami metropolitalnymi i zasad ich finansowania ${ }^{25} . \mathrm{Na}$ podstawie zgromadzonych wniosków i opinii wyznaczono kierunki kolejnych działań rządu zmierzających do przygotowywania zmian prawnych i organizacyjnych mających na celu usprawnienie funkcjonowania aglomeracji miejskich ${ }^{26}$.

W listopadzie 2011 roku w wyniku prac Zespołu ds. samorządu terytorialnego (funkcjonującego w ramach Forum Debaty Publicznej „Samorząd tery torialny dla Polski" przy Prezydencie RP) i przeprowadzonych szerokich konsultacji społecznych, zakończono prace nad ostateczną wersją projektu ustawy o wzmocnieniu udziału mieszkańców w samorządzie terytorialnym, współdziałaniu gmin, powiatów i województw oraz o zmianie niektórych ustaw ${ }^{27}$, który w sierpniu 2013 roku wpłynął do Sejmu jako prezydencki projekt ustawy o współdziałaniu w samorządzie terytorialnym na rzecz rozwoju lokalnego i regionalnego oraz o zmianie niektórych ustaw ${ }^{28}$. Jednym z jego założeń było wzmocnienie współdziałania między różnymi kategoriami j.s.t. W celu umożliwienia współpracy sąsiadujących jednostek samorządu lokalnego w zakresie zagospodarowania przestrzennego, polityki rozwoju oraz wspólnych przedsięwzięć i zadań mających znaczenie dla całego obszaru proponowano dobrowolne tworzenie zespołów współpracy terytorialnej przez gminy stanowiące ciągły przestrzennie układ osadniczy. W skład zespołu mógłby wejść także powiat, o ile przynajmniej jedna gmina wchodząca w jego skład byłaby członkiem zespołu. Zespoły te, posiadające osobowość prawną, miały funkcjonować na zasadach określonych w ustawie, a w zakresie w niej nieuregulowanym odpowiednio według przepisów o związkach międzygmin-

24 Więcej na temat prezentowanej koncepcji B. Dolnicki w pracach: Koncepcja powiatu metropolitalnego, „Administracja: Teoria, Dydaktyka, Praktyka” 2011, nr 4, s. 35-63; Założenia ustawy o powiecie metropolitalnym Górnego Ślaska i Zagłębia, [w:] Formy współdziałania jednostek samorzadu terytorialnego, red. B. Dolnicki, Warszawa 2012, s. 90-98; Założenia ustawy o powiecie metropolitalnym Aglomeracji Górnośląskiej, „Przegląd Prawa Publicznego” 2013, nr 12, s. 72-88; Koncepcja ustawy o powiecie metropolitalnym Aglomeracji Górnoślaskiej, [w:] Miasta, aglomeracje, metropolie w nurcie globalnych przemian, red. K. Kuć-Czajkowska, M. Sidor, Lublin 2014, s. 203-217; Koncepcja powiatu metropolitalnego, „Samorząd Terytorialny” 2014, nr 7-8, s. 9-17.

25 Zielona Księga dotycząca obszarów metropolitalnych, Ministerstwo Administracji i Cyfryzacji, Warszawa 2012.

${ }^{26}$ Biała księga obszarów metropolitalnych, Ministerstwo Administracji i Cyfryzacji, Warszawa 2013.

27 Projekt ustawy z dnia 25 marca 2011 r. o wzmocnieniu udziału mieszkańców w samorządzie terytorialnym, współdziałaniu gmin, powiatów i województw oraz o zmianie niektórych ustaw (www.prezydent.pl).

28 Druk Sejmu VII kadencji nr 1699. 
nych. W uzasadnieniu projektu zauważono jednak, że przedstawiona propozycja jest adresowana przede wszystkim do zespołów położonych dookoła miast małej i średniej wielkości i nie wykluczono konieczności uchwalenia odrębnych ustaw ukierunkowanych na poszczególne obszary metropolitarne (postępowanie legislacyjne nie zakończyło się uchwaleniem ustawy z powodu upływu kadencji Sejmu).

\section{GENEZA, KONCEPCJA I OGÓLNA OCENA PIERWSZEJ USTAWY O ZWIĄZKACH METROPOLITALNYCH}

W sierpniu 2013 roku złożono w Sejmie poselski projekt ustawy o powiecie metropolitalnym ${ }^{29}$, który procedowano przez dwa lata. Pierwotnie powiat metropolitalny miał być zorganizowany jako lokalna wspólnota samorządowa. Byłby tworzony przez Radę Ministrów zarówno z jej samodzielnej inicjatywy, jak i na wniosek zainteresowanej rady gminy, powiatu lub miasta na prawach powiatu. Powiat metropolitalny realizowałby zadania własne (w zasadzie określone analogicznie jak we wcześniej prezentowanych projektach) oraz zlecone ustawą z zakresu administracji rządowej. Wyposażony zostałby w dwa kolegialne organy — stanowiący i kontrolny (piętnastoosobową radę, wybieraną w wyborach bezpośrednich, ze starostą jako przewodniczącym) oraz wykonawczy (trzyosobowy zarząd, wybierany przez radę, ze starostą jako przewodniczącym). W zakresie właściwości rady i zadań zarządu w projekcie zaproponowano rozwiązania analogiczne jak przyjęte w ustawach samorządowych dla organów j.s.t. Powiat metropolitalny mógłby tworzyć związki z innymi gminami i powiatami, a także zawierać porozumienia $\mathrm{z}$ j.s.t. oraz z organami administracji rządowej w sprawie wykonywania zadań publicznych z zakresu administracji rządowej. Mógłby także tworzyć stowarzyszenia z gminami, powiatami i województwami. Określono również zasady udzielania pomocy przez powiat metropolitalny oraz związki i stowarzyszenia j.s.t. Podstawą gospodarki finansowej miała być uchwała budżetowa. Projekt proponował przyjęcie zmian między innymi w ustawie o dochodach j.s.t., w zakresie stworzenia katalogu źródeł dochodów własnych oraz subwencji z budżetu państwa dla powiatu metropolitalnego. Pierwotna wersja projektu ustawy o powiecie metropolitalnym spotkała się ze zróżnicowaną oceną, wyrażaną zarówno w ramach procesu legislacyjnego, jak i w piśmiennictwie ${ }^{30}$.

Zwieńczeniem dwuletniego procedowania projektu ustawy o powiecie metropolitalnym było przyjęcie w dniu 9 października 2015 roku ustawy o związkach metropolitalnych ${ }^{31}$. W toku prac parlamentarnych, na etapie prac podkomisji

29 Druk nr 2107 Sejmu VII kadencji.

30 Zob. P. Antkowiak, Poselski projekt ustawy o powiecie metropolitalnym - progres czy regres $w$ reformowaniu samorzadu terytorialnego w Polsce?, „Środkowoeuropejskie Studia Polityczne" 2016, nr 4, s. 100-108.

31 Tekst pierwotny Dz.U. z 2015 r. poz. 1890. 
nadzwyczajnej do rozpatrzenia poselskiego projektu ustawy o powiecie metropolitalnym, doszło do zmiany koncepcji modelu zarządzania obszarem metropolitalnym i odstąpiono od idei utworzenia powiatu metropolitalnego na rzecz przyjęcia rozwiązania funkcjonalnego w postaci związku metropolitalnego. Przyjęto, że związek metropolitalny, wyposażone w osobowość prawną zrzeszenie j.s.t. położonych $\mathrm{w}$ danym obszarze metropolitalnym, nie stanowi nowej kategorii j.s.t. i nie należy w odniesieniu do niego stosować analogii do związku komunalnego. Obszarem metropolitalnym, na którym może zostać ustanowiony związek, jest spójna pod względem przestrzennym strefa oddziaływania miasta będącego siedzibą wojewody lub sejmiku województwa, charakteryzująca się istnieniem mocnych powiązań funkcjonalnych oraz zaawansowaniem procesów urbanizacyjnych, zamieszkana przez co najmniej 500 tys. mieszkańców (tym samym ustawodawca określił dopuszczalną liczbę obszarów metropolitalnych na terenie kraju). Związek metropolitalny może zostać utworzony zarówno przez Radę Ministrów z własnej inicjatywy, jak i na wniosek rady gminy położonej w granicach obszaru metropolitalnego, w celu realizacji ustawowo określonych zadań publicznych w zakresie kształtowania ładu przestrzennego, rozwoju obszaru związku, publicznego transportu zbiorowego na obszarze związku, współdziałania w ustalaniu przebiegu dróg krajowych i wojewódzkich na obszarze związku oraz promocji obszaru metropolitalnego. Ponadto związek mógłby wykonywać inne zadania publiczne, na podstawie porozumień zawartych $\mathrm{z}$ j.s.t. oraz organami administracji rządowej. Związek metropolitalny został zorganizowany na wzór rozwiązań przyjętych w ustawie o samorządzie województwa. Miałby dwa organy - stanowiący i kontrolny (zgromadzenie, składające się z delegatów gmin i powiatów wchodzących w skład związku — po dwóch z każdej j.s.t.) oraz wykonawczy (trzyosobowy zarząd, wybierany przez zgromadzenie). Podstawą gospodarki finansowej ma być uchwała budżetowa. Katalog źródeł dochodów związków metropolitalnych został określony natomiast w znowelizowanej ustawie o dochodach j.s.t. Związek mógłby w celu wykonywania swoich zadań tworzyć jednostki organizacyjne oraz zawierać porozumienia z j.s.t. i organami administracji rządowej. Mógłby także udzielać pomocy j.s.t. i innymi związkom metropolitalnym oraz tworzyć z nimi stowarzyszenia. Do nadzoru nad działalnością związku metropolitalnego odpowiednio stosuje się przepisy o nadzorze zawarte w ustawie o samorządzie województwa. Rozwiązania proponowane w ustawie o związkach metropolitalnych nie zostały jednak wykorzystane w praktyce, ponieważ w okresie jej obowiązywania Rada Ministrów nie wydała rozporządzenia ustalającego granice obszaru metropolitalnego i tworzącego związek metropolitalny. Ustawa o związkach metropolitalnych straciła moc obowiązującą w związku z wejściem w życie ustawy z dnia 9 marca 2017 roku o związku metropolitalnym w województwie śląskim ${ }^{32}$ (pozostało

32 Dz.U. z 2017 r. poz. 730. 
jednak w mocy wiele zmian wprowadzonych ustawą z 2015 roku, w tym także mających znaczenie dla planowania przestrzennego na obszarze metropolitalnym).

Mimo że przyjęcie ustawowych systemowych rozwiązań prawnych dotyczących obszarów metropolitalnych było postulowane od wielu lat, wprowadzone ustawą o związkach metropolitalnych regulacje zostały ocenione dość krytycznie. W piśmiennictwie negatywnie oceniono między innymi uniwersalny charakter ustawy i podnoszono, że stanowi rozwiązanie kompromisowe, którego celem jest stworzenie ogólnych norm prawnych funkcjonowania metropolii w ogóle, nie zaś do rozwiązania problemów specyficznych dla danego terytorium z uwzględnieniem istniejących form współpracy samorządów i sposobu organizacji wykonywania zadań publicznych ${ }^{33}$. Podnoszono też, że ustalony przez ustawodawcę zakres działania związku metropolitalnego nie do końca wypełnia lukę zadaniowo-kompetencyjną, uniemożliwiającą zaspokajanie zbiorowych potrzeb mieszkańców obszarów metropolitalnych ${ }^{34}$. Zastrzeżenia zgłaszano także do przyjętego w ustawie sposobu regulacji tworzenia i funkcjonowania związków metropolitalnych, widząc w nim centralistyczny i autorytatywny model relacji państwo-samorząd, rzadko spotykany w innych państwach europejskich ${ }^{35}$. Określone potrzeby kontynuowania prac nad przyjęciem nowych rozwiązań prawnych dotyczących obszarów metropolitalnych, już po wejściu w życie ustawy o związkach metropolitalnych, zgłaszały także same j.s.t., jednocześnie wskazując mankamenty dotychczas obowiązującej ustawy uniemożliwiające skuteczne utworzenie takiego związku i ewentualnie mogące osłabiać działalność jego organów.

\section{INICJATYWY LEGISLACYJNE DOTYCZĄCE PROBLEMATYKI METROPOLII I OBSZARÓW METROPOLITALNYCH PODEJMOWANE W VIII KADENCJI SEJMU (DO 31 GRUDNIA 2017 ROKU)}

W VIII kadencji Sejmu do grudnia 2017 roku złożono trzy kolejne projekty ustaw odnoszące się do problematyki metropolii i obszarów metropolitalnych. W styczniu 2017 roku wpłynął do Sejmu rządowy projekt ustawy o związku metropolitalnym w województwie śląskim ${ }^{36}$, który stał się podstawą uchwalonej w dniu

33 Tak T. Moll, Ustawa o zwiąkach metropolitalnych - rozwiąanie stuszne czy kompromisowe?, „Przegląd Prawa Publicznego” 2017, nr 7-8, s. 150-151.

34 Tak T. Bąkowski, $W$ poszukiwaniu wykonawcy zadań metropolitalnych, [w:] Charakter i konstrukcja zadań samorzadu terytorialnego, red. M. Stec, S. Płażek, Warszawa 2017, s. 64 i 65.

35 Tak D. Sześciło, Opinia w sprawie ustawy z 9 października 2015 r. o zwiąkach metropolitalnych, „Opinie i Analizy” 2016, nr 1, s. 7. Zob. także F. Nalikowski, Związki metropolitalne. Szansa na rozwój czy negacja zasady zrównoważonego rozwoju?, [w:] Samorząd terytorialny w Polsce $i$ w Europie. Aktualne problemy i wyzwania, red. K. Czarnecki, A. Lutrzykowski, R. Musiałkiewicz, Włocławek 2017, s. 183.

36 Druk Sejmu VIII kadencji nr 1211. 
9 marca 2017 roku ustawy o związku metropolitalnym w województwie śląskim ${ }^{37}$. Przyjęto, że na obszarze województwa śląskiego może zostać utworzony związek metropolitalny, stanowiący zrzeszenie gmin województwa śląskiego, charakteryzujących się istnieniem silnych powiązań funkcjonalnych oraz zaawansowaniem procesów urbanizacyjnych, położonych na obszarze spójnym pod względem przestrzennym, który zamieszkuje co najmniej 2 mln mieszkańców. W skład tego związku wchodzi miasto na prawach powiatu Katowice. Rada Ministrów została upoważniona do utworzenia związku oraz ustalenia (zmiany) jego obszaru i granic, mając na względzie istniejące formy współpracy gmin wchodzących w skład związku metropolitalnego, powiązania funkcjonalne i zaawansowanie procesów urbanizacyjnych oraz układ osadniczy i przestrzenny uwzględniający więzi społeczne, gospodarcze i kulturowe na tym obszarze. Wydała w tej sprawie rozporządzenie w dniu 26 czerwca 2017 roku, tworząc związek metropolitalny o nazwie „Górnośląsko-Zagłębiowska Metropolia" ${ }^{38}$. Ustawodawca, ustalając konstrukcję związku metropolitalnego w województwie śląskim, nawiązał do rozwiązań ustrojowych przyjętych w ustawie o związkach metropolitalnych z 2015 roku, z pewnymi niezbędnymi modyfikacjami. Związek będzie wykonywał zadania własne oraz zadania zlecone. Katalog zadań obowiązkowych związku obejmuje zadania publiczne w zakresie: kształtowania ładu przestrzennego; rozwoju społecznego i gospodarczego obszaru związku; planowania, koordynacji, integracji oraz rozwoju publicznego transportu zbiorowego; zrównoważonej mobilności miejskiej; metropolitalnych przewozów pasażerskich oraz współdziałania w ustalaniu przebiegu dróg krajowych i wojewódzkich na obszarze związku, a także promocji związku metropolitalnego i jego obszaru. Związek będzie mógł także realizować zadania publiczne należące do zakresu działania gminy, powiatu lub samorządu województwa (ewentualnie koordynować ich realizację). Zgromadzenie związku składa się z delegatów gmin wchodzących w skład związku — po jednym z każdej gminy. Będzie podejmować uchwały podwójną większością głosów, chyba że ustawa stanowi inaczej. Zarząd związku jest pięcioosobowy. Ustawowe przyjęcie zasad tworzenia, organizacji i funkcjonowania związku metropolitalnego w województwie śląskim oznacza odstąpienie od koncepcji jednolitych ustawowych rozwiązań dla wszystkich obszarów metropolitalnych na rzecz przyjmowania, w razie konieczności, odrębnych (kolejnych) ustaw dla poszczególnych obszarów ${ }^{39}$.

37 Dz.U. z 2017 r. poz. 730.

38 Rozporządzenie Rady Ministrów z dnia 26 czerwca 2017 roku w sprawie utworzenia w województwie śląskim związku metropolitalnego pod nazwą „Górnośląsko-Zagłębiowska Metropolia” (Dz.U. z 2017 r. poz. 1290).

39 Mimo stosunkowo niedługiego okresu obowiązywania ustawy z 2017 roku formułowane są już w piśmiennictwie pierwsze, ogólne, oceny przyjętych w niej rozwiązań. Zob. między innymi R. Gawłowski, op. cit., s. 186. 
W grudniu 2016 roku wpłynął do Sejmu poselski projekt ustawy o Poznańskim Związku Metropolitalnym ${ }^{40}$. Wzorowany był na projekcie ustawy o związku metropolitalnym w województwie śląskim i wykorzystywał niektóre rozwiązania przyjęte w ustawie o związkach metropolitalnych. Zakładał utworzenie związku metropolitalnego na obszarze województwa wielkopolskiego, będącego zrzeszeniem gmin i powiatów położonych w województwie wielkopolskim, obejmującego spójny pod względem przestrzennym obszar oddziaływania miasta na prawach powiatu Poznania i charakteryzujący się istnieniem silnych powiązań funkcjonalnych, zamieszkany przez co najmniej 600 tys. mieszkańców. Projekt ten został odrzucony przez Sejm w pierwszym czytaniu ustawy w marcu 2017 roku.

W styczniu 2017 roku wpłynął do Sejmu poselski projekt ustawy o ustroju miasta stołecznego Warszawy ${ }^{41}$, zawierający propozycję uregulowania pozycji prawnej, zasad organizacji i funkcjonowania, miasta stołecznego Warszawy jako metropolitalnej jednostki samorządu tery torialnego. Projekt ten został skierowany do pierwszego czytania, ale w kwietniu 2017 roku wnioskodawca go wycofał.

\section{PODSUMOWANIE}

Przedstawione koncepcje, założenia i projekty ustaw oraz przyjmowane rozwiązania prawne prezentują ewolucję w sposobie rozumienia problemów obszarów metropolitalnych. Ujawniają zróżnicowane podejście co do zakresu proponowanej regulacji oraz modelu statusu prawnego takich obszarów (począwszy od rozwiązań z wykorzystaniem dobrowolnych form współpracy aż po utworzenie nowej kategorii j.s.t. i dokonanie zmian w podziale terytorialnym państwa). Bez wątpienia poszukiwanie optymalnego modelu zarządzania obszarami metropolitalnymi i konieczność instytucjonalizacji obszarów metropolitalnych była wielokrotnie podnoszona $\mathrm{w}$ różnych środowiskach ze zmienną intensywnością, $\mathrm{w}$ tym także w trakcie prac nad kolejnymi etapami reformy administracji publicznej. Nie rozwiązały specyficznych problemów obszarów metropolitalnych ani powołanie miast na prawach powiatu, ani inne wprowadzone rozwiązania jedynie fragmentarycznie umożliwiające realizację zadań metropolitalnych ${ }^{42}$. Również w praktyce, stosując określone przez ustawodawcę formy współdziałania, poszukiwano najwłaściwszego sposobu wykonywania zadań metropolitalnych (w szczególności w zakresie planowania i zagospodarowania przestrzennego, zarządu dróg i transportu zbiorowego). Nadal prowadzony jest dyskurs o optymalnym kształcie rozwiązań ustrojowych,

40 Druk Sejmu VII kadencji nr 1196.

41 Druk Sejmu VIII kadencji nr 1259.

42 Na przykład obszary funkcjonalne, uregulowane w ustawie o planowaniu i zagospodarowaniu przestrzennym, dla których uchwala się plan zagospodarowania przestrzennego, czy Zintegrowane Inwestycje Terytorialne, realizowane na terenie miast będących siedzibą władz samorządu województwa lub wojewody i obszarów powiązanych z nimi funkcjonalnie. 
organizacyjnych i finansowych, uwzględniających specyfikę funkcjonowania obszarów metropolitalnych. Osiągnięto już porozumienie co do wyboru ustawowego rozwiązania funkcjonalnego na podstawie konstrukcji związku metropolitalnego i katalogu zadań metropolitalnych. Nadal jednak nie uzyskano powszechnej akceptacji dokonanego wyboru charakteru regulacji modelu zarządzania obszarami metropolitalnymi. Sam ustawodawca dość szybko zmienił stanowisko w tej sprawie, odstępując od uchwalonych rozwiązań o charakterze uniwersalnym na rzecz rozwiązań przeznaczonych dla konkretnego obszaru. Oznaczać to może niechęć ustawodawcy do tworzenia kolejnych obszarów metropolitalnych wymagających zindywidualizowanego podejścia nawet $\mathrm{w}$ przypadku uzasadnionych potrzeb zgłaszanych przez środowiska samorządowe.

\title{
THE SHAPING OF THE CONCEPT OF METROPOLITAN ASSOCIATIONS IN POLAND AFTER 1990
}

\author{
Summary
}

The local self-government system in Poland has been evolving since its restitution in 1990. One of the major problems discussed in recent years is the issue of the system of metropolitan areas, metropolises and agglomerations (what was before referred to as large cities). The issue is complex, which is reflected in, i.a., attempts to develop systemic solutions regarding large cities and hinterlands. The aim of the paper is to analyze draft laws put forth by various entities relating to this very issue, including their underlying assumptions. The draft laws and assumptions presented in the paper were developed mostly in response to the reality of the collaboration of large urban centers and adjacent municipalities demonstrating clearly that the solutions based on the institution of voluntary municipal unions do not yield the desired effects for large cities and metropolitan areas. In spite of the common belief that some legislative solutions regarding the system of government regulating the legal status of metropolitan areas must be adopted in Poland, the first Act on metropolitan areas was passed only in 2015, and even a single municipal association has not been established on its grounds.

Keywords: metropolitan area, metropolitan union, metropolitan district

\section{BIBLIOGRAFIA}

Antkowiak P., Poselski projekt ustawy o powiecie metropolitalnym - progres czy regres $w$ reformowaniu samorzadu terytorialnego w Polsce?, „Środkowoeuropejskie Studia Polityczne” 2016, $\mathrm{nr} 4$.

Bąkowski T., W poszukiwaniu wykonawcy zadań metropolitalnych, [w:] Charakter i konstrukcja zadań samorządu terytorialnego, red. M. Stec, S. Płażek, Warszawa 2017.

Dolnicki B., Koncepcja powiatu metropolitalnego, „Administracja: Teoria, Dydaktyka, Praktyka” 2011, nr 4 .

Dolnicki B., Koncepcja powiatu metropolitalnego, „Samorząd Terytorialny” 2014, nr 7-8. 
Dolnicki B., Koncepcja ustawy o powiecie metropolitalnym Aglomeracji Górnoślaskiej, [w:] Miasta, aglomeracje, metropolie w nurcie globalnych przemian, red. K. Kuć-Czajkowska, M. Sidor, Lublin 2014.

Dolnicki B., Ustrój metropolii - wspótczesne koncepcje, „Administracja Publiczna. Studia Krajowe i Międzynarodowe" 2010, $\mathrm{nr} 2$.

Dolnicki B., Założenia ustawy o powiecie metropolitalnym Aglomeracji Górnoślaskiej, „Przegląd Prawa Publicznego" 2013, nr 12.

Dolnicki B., Założenia ustawy o powiecie metropolitalnym Górnego Śląska i Zagłębia, [w:] Formy współdziałania jednostek samorzadu terytorialnego, red. B. Dolnicki, Warszawa 2012.

Dyskusja o powiatach, t. 2. Projektowanie ustawodawstwa powiatowego, cz. 1, red. R. Sowiński, Poznań 1994.

Edwarczyk B., Rozwój obszarów metropolitalnych w świetle transformacji samorządu terytorialnego w Polsce w latach 1990-2014, ,,Ruch Prawniczy, Ekonomiczny i Socjologiczny” 2015, z. 3.

Faliński S., Warszawski samorząd terytorialny w latach 1990-2002. Geneza, ustrój, idee ustrojowe, aktywność, Warszawa 2013.

Gawłowski R., Metropolie jako szczególne jednostki samorządu terytorialnego, [w:] R. Gawłowski, P. Machalski, K. Makowski, Samorzad terytorialny w systemie administracji publicznej, Warszawa 2017.

Gronkiewicz-Waltz H., Jakacka B., Ewolucja samorzadu warszawskiego, [w:] Misja publiczna, wspólnota, państwo: studia z prawa i administracji. Księga dedykowana pamięci profesora Michała Kuleszy, t. 1, Wrocław 2016.

Ignasiak-Szulc A., Dylematy ,,dekretowania” zasad wspierania procesu metropolizacji w Polsce, [w:] Wielkie miasta, aglomeracje, metropolie, red. S. Flejterski, „Ekonomiczne Problemy Usług" 30, Szczecin 2009.

Izdebski H., Samorząd terytorialny. Podstawy ustroju i działalności, Warszawa 2014.

Izdebski H., Zadania metropolitalne i instytucjonalne sposoby ich realizacji, „Samorząd Terytorialny" 2010, nr 6 .

Jaworska-Dębska B., O istocie związów metropolitalnych, [w:] O prawie administracyjnym i administracji. Refleksje. Księga jubileuszowa dedykowana Profesor Małgorzacie Stahl, red. B. Jaworska-Dębska, Łódź 2017.

Jaworska-Dębska B., Poszukiwanie dróg optymalizacji ustroju dużych miast, „Samorząd Terytorialny" 1992, nr 12.

Kieres L., Uwagi o projekcie z dnia 29 lipca 1993 r. ustawy o samorzadzie powiatowym, [w:] Dyskusja o powiatach, t. 2. Projektowanie ustawodawstwa powiatowego, cz. 1, red. R. Sowiński, Poznań 1994.

Knosala E., Gołuch A., Stasikowski R., Uwagi w sprawie koncepcji ustrojowej aglomeracji ślaskiej wraz z projektem ustawy o Regionalnym Związku Komunalnym ,Silesia”, „Samorząd Terytorialny" 2007, nr 12.

Knosala E., Stasikowski R., Prawne i organizacyjne problemy funkcjonowania aglomeracji ze szczególnym uwzględnieniem aglomeracji śląskiej, [w:] Problemy wspótczesnego ustrojoznawstwa. Ksiega Jubileuszowa Procesora Bronisława Jastrzębskiego, Olsztyn 2007.

Kopyciński P., $W$ kierunku trzeciej reformy samorządu terytorialnego, „Samorząd Terytorialny” 2016, nr 7-8.

Kulesza M., Budowanie samorządu. Wybór tekstów ze „Wspólnoty” 1990-2007, Warszawa 2008.

Kulesza M., Kilka uwag o zarządzaniu aglomeracją miejską. Wyzwania instytucjonalne i prawne, „Samorząd Terytorialny” 2010, nr 6.

Kulesza M., Miejski program pilotażowy reformy administracji publicznej (ogólne omówienie), „Samorząd Terytorialny” 1995, nr 12.

Moll T., Ustawa o związkach metropolitalnych — rozwiązanie stuszne czy kompromisowe?, „Przegląd Prawa Publicznego" 2017, nr 7-8. 
Nalikowski F., Związki metropolitalne. Szansa na rozwój czy negacja zasady zrównoważonego rozwoju?, [w:] Samorzad terytorialny w Polsce $i$ w Europie. Aktualne problemy $i$ wyzwania, red. K. Czarnecki, A. Lutrzykowski, R. Musiałkiewicz, Włocławek 2017.

Ofiarska M., Koncepcje i kierunki ewolucji form wspótdziałania gmin we Francji - wnioski dla Polski, [w:] Finanse publiczne i prawo finansowe. Realia i perspektywy zmian. Ksiega Jubileuszowa dedykowana Profesorowi Eugeniuszowi Ruśkowskiemu, Białystok 2012.

Podgórski K., Uwagi i propozycje szczególowe do projektu ustawy o samorzadzie powiatowym (z dnia 10 sierpnia 1993 r.), [w:] Dyskusja o powiatach, t. 2. Projektowanie ustawodawstwa powiatowego, cz. 1, red. R. Sowiński, Poznań 1994.

Sześciło D., Opinia w sprawie ustawy z 9 października 2015 r. o zwiąkach metropolitalnych, „Opinie i Analizy” 2016, nr 1.

Władyka A., Wójcik M., Zawicki M., Powstawanie miejskich stref usług publicznych, [w:] Od miejskiej strefy ustug publicznych do powiatu, red. J. Hausner, S. Mazur, Kraków 1998.

Zachariasz I., Koncepcja utworzenia powiatów metropolitalnych, [w:] Sprawne państwo. Propozycje zmian w funkcjonowaniu jednostek samorzadu terytorialnego w Polsce, red. P. Kopyciński, Kraków 2015. 